\title{
Study of Seed Mycoflora in Different Samples of Abelmoschus esculentus (L.) Moench
}

\author{
Praveen Banvasi*, C. P. Khare, G. K. Awadhiya, Veer Singh and Dheeraj Baghel \\ Department of Plant Pathology, Indira Gandhi Krishi Vishvavidhalaya, \\ Raipur, (CG), 492012, India \\ *Corresponding author
}

\section{A B S T R A C T}

\section{Keywords}

Aspergillus niger

(2.05\%), Rhizopus

sp. $(1.93 \%)$,

Chaetomium sp. $(1.87 \%)$

\section{Article Info}

Accepted:

17 November 2019

Available Online:

10 December 2019
Health status of okra seed samples collected from six different location (Raipur, Kawardha, Bilaspur, Ambikapur, Jashpur and Dhamtari) of Chhattisgarh was studied. By incubation methods (standard blotter, agar plate and 2, 4-D), in total 14 mycoflora (Alternaria sp., Aspergillus flavus, Aspergillus fumigatus, Aspergillus niger, Chaetomium sp., Colletotrichum sp., Curvularia sp., Fusarium sp., Memnoniella sp., Nigrospora sp., Penicillium sp., Rhizopus sp., Sterile mycelium, Trichoderma sp.) were detected with varying frequencies in different samples and methods. Frequency of mycoflora was highest $2.49 \%$ in Bilaspur sample followed by $2.24 \%$ in Raipur, $2.16 \%$ in Ambikapur, $2.08 \%$ in jashpur, $2.00 \%$ in Kawardha and lowest mean frequency was $0.83 \%$ in Dhamtari sample. In overall mycoflora detected by three incubation methods average frequency was highest of Fusarium sp.(22.94 \%) followed by Alternaria sp.(18.49\%), Aspergillus flavus (18.38\%), Nigrospora sp. (5.99\%), Curvularia sp. (4.60\%), Trichoderma sp. (2.58 \%), Sterile mycelium (2.55 $\%)$, Aspergillus fumigates (2.44 \%), Aspergillus niger (2.05\%), Rhizopus sp. (1.93 $\%)$, Chaetomium sp. (1.87 \%), Memnoniella sp. (1.55\%), Colletotrichum sp.(1.44\%) and lowest frequency was Penicillium sp. (1.33\%)

\section{Introduction}

Okra, Abelmoschus esculentus (L.) Moench, is an important vegetable crop grown mainly in the tropical or sub-tropical regions during summer and rainy season. Hence, it is classified as a warm season crop (National Research Council, 2006). The major okra producing countries in the world include India
(6.35 million tons), Nigeria (1.10 million tons), Iraq (0.14 million tons), Côte d'Ivoire (0.13 million tons) and Pakistan (0.10 million tons) (Anonymous 2013). Nutritional profile of okra showed that it contains saturated fats, carbohydrates, proteins, vitamin A, B6, B12, folate, ribofalvin, niacin, pentothenic acid, Vitamin C, and E etc., it also contains magnesium, phosphorous, potassium, zinc, 
sodium, copper, manganese and selenium. The seeds also contains dietary fiber and sugars (Anon., 2012). The mucilage from okra is suitable for industrial and medicinal application and could be applied as plasma replacement or blood volume expander (Arapitsas, 2008). The leaf buds and flowers are also edible. The seed when roasted and ground can be used as coffee additive or substitute (Moekchantuk and Kumar, 2004). The roots and stems of okra are used for clarification of sugarcane juice from which gur or brown sugar is prepared (Chauhan, 1972).

Its medicinal value has also been reported in curing ulcers and relief from haemorrhoids (Adams, 1975). Okra seeds contain a considerable amount of good quality oil and protein and can be used as a substitute for coffee (Valeriana, 2002). Various factors are responsible for low yield of okra. Seed-borne fungal diseases are often the main cause. In most regions of the world, okra crop is produced in large quantities, poor agronomic practices and storage conditions including improper drying and inadequate structures have contributed to the reportedly high prevalence of fungal contaminants of okra especially seed-borne molds. There are 10 seed-borne diseases of okra which are caused by at least 14 different seed-borne fungal pathogens (Fakir, 2000). Macrophomina phaseolina and Colletotrium dematium were found seed-borne in okra and these two fungi were responsible for germination failure, pre and post-emergence damping off of the seedlings and also capable of causing infection to the older plants of the crop. Their studies also indicated that the two pathogens become seed-borne through okra seeds. (Fakir et al., 1977). Macrophomina phaseolina and Colletotrichum dematium are responsible for dieback. Macrophomina phaseolina alone can also cause stem rot (Fakir and Mridha, 1985). Among these fungal pathogens Colletotrichum dematium and Macrophomina phaseolina are both seed transmitted.

\section{Materials and Methods}

The experiment was conducted during the period of Kharif and Rabi season of 2016-17. Several methods of seed health testing have been developed for the detection of fungi (Anon, 1959 and 1966; Neergaard, 1979; Richardson, 1990). Some of the most suitable procedures have been recommended by the International Seed Testing Association (ISTA, 1999). The following standard methods recommended were used in the present studies of seed health evaluation. i) Assessment by Blotter Method (ISTA, 1999) ii) Assessment by Agar Plate Method (Muskett and Malone, 1941) iii) Assessment by 2, 4-D method (Neergaard, 1979) iv) Direct observation Method through dry seed examination (ISTA, 1999). All the analysis and calculation of mean, frequency was done by Microsoft office excel 2007.

\section{Results and Discussion}

A total of six seed samples of okra (Abelmoschus esculentus L. Moench) were collected from 6 farmers house of six locations of Chhattisgarh viz. Raipur, Kawardha, Bilaspur, Ambikapur, Jashpur and Dhamtari.

Fourteen fungal genera were prevalent in okra seeds during incubation test. The fungal genera were Alternaria sp., Aspergillus flavus, Aspergillus fumigatus, Aspergillus niger, Chaetomium sp., Colletotrichum sp., Curvularia sp., Fusarium sp., Memnoniella sp., Nigrospora sp., Penicillium sp., Rizopus sp., Sterile mycelium, Trichoderma sp..

Association of Alternaria sp. with seed sample of different ecological region of Chhattisgarh was recorded highest in Kawardha (26\%) and 
lowest in Raipur (13\%), statistically similar association of Alternaria sp. were observed in Bilaspur (17\%), Ambikapur (20.66\%), Jashpur (15.33) and Dhamtari (19\%).

Prevalence of Aspergillus flavus was found highest $(27.33 \%)$ in the seed sample of Dhamtari and lowest in Jashpur (12.33\%). Second highest prevalence was found in the seed samples of Ambikapur (22\%). Statistically similar association of Aspergillus flavus were observed in Raipur(13\%), Kawardha (19.33\%) and Bilaspur (16.33\%).

The occurrence of Aspergillus fumigatus was recorded highest in the seed samples collected from Ambikapur (4.33\%) and lowest in the sample of Bilaspur (1\%).While Aspergillus fumigatus also showed statistically similar results in the sample of Jashpur (2\%) and not recorded in the sample of Raipur, Kawardha and Dhamtari.

Aspergillus niger recorded highest in the sample of Raipur (5\%) and lowest in Kawardha (1\%) and Jashpur (1\%). Similarly Aspergillus niger also recorded in rest all the samples (Bilaspur (1.33\%), Ambikapur $(1.66 \%)$ and Dhamtari (2.33\%).

Chaetomium sp. was found in the sample of Raipur (1.16\%), Kawardha (3\%), Jashpur (2\%) and Dhamtari (1.33\%), and not found in Bilaspur and Ambikapur.

Colletotrichum sp. recorded in the sample of Raipur (3\%) with highest frequency and lowest in Dhamtari $(0.33 \%)$ also recorded in the sample of Ambikapur (1\%) and not recorded from the sample of Kawardha, Bilaspur and Jashpur.

Occurrence of Curvularia sp. was highest in the seed sample collected from Raipur $(10.33 \%)$ and lowest in the sample of Bilaspur (1\%). Curvularia sp. also showed in the sample of Kawardha (4.33\%), Ambikapur (3.33\%), Jashpur (2\%), and Dhamtari (6.66\%).

Prevalence of Fusarium sp. was found highest in the seed sample of Bilaspur (33.33\%) and lowest in Raipur (17.66\%). Statistically similar association of Aspergillus flavus were observed in Kawardha (18\%), Ambikapur (20\%), Jashpur (26\%), and Dhamtari $(22.66 \%)$.

Memnoniella sp. recorded highest in the sample of Jashpur (3\%) and lowest in sample of Kawardha (0.66\%). Also Memnoniella sp. was found on sample of Dhamtari (1\%) and not found on sample of Raipur, Bilaspur and Ambikapur.

Association of Nigrospora sp.was observed highest in the sample of Ambikapur (7.66\%) and lowest in Kawardha (4\%). Nigrospora sp.also associated with Bilaspur (5.66\%), Jashpur (6.33\%), Dhamtari (6.33\%), and not found in the sample of Raipur.

Penicillium sp. was highest associated with the sample of Kawardha (2\%) and lowest with sample of Dhamtari $(0.66 \%)$ also found in sample of Raipur (1.66\%), Ambikapur (1\%), Jashpur $(1.33 \%)$ and not found in sample of Bilaspur.

Rhizopus sp. was highest with the sample of Jashpur (3.66\%) and lowest with Raipur (0.66\%). Rhizopus sp. similarly associated with the sample of Kawardha (1\%), Bilaspur (3.33\%), Dhamtari (1\%) and not associated with sample of Ambikapur.

Prevalance of sterile mycelium was recorded highest in the sample of Kawardha (3\%) and lowest in Raipur (2.33\%) and Jashpur (2.33) also. Sterile mycelium was not found in the sample of Bilaspur, Ambikapur and Dhamtari. Occurrence of Trichoderma sp. was found highest in the sample of Raipur (4.33\%) and 
lowest in the sample of Jashpur (1\%). Trichoderma sp. also found in the sample from Bilaspur (1.66\%) and Ambikapur $(3.33 \%)$ and not found in sample of Kawardha and Dhamtari.

In the sample of Raipur, 11 species of mycoflora were recorded among this highest frequency was Fusarium (17.66\%) and lowest was Rhizopus sp. (0.66\%). Similarly Alternaria sp. (13\%), Aspergillus flavus (13\%), Aspergillus niger (5\%), Chaetomium sp. (1.16\%), Colletotrichum sp. (3\%), Curvularia sp. (10.33\%), Penicillium sp.(1.66\%), Sterile mycelium (2.33\%) and Trichoderma sp. (4.33\%) were also recorded in this sample.

From the sample of Kawardha 11 species were found in this, highest frequency was Alternaria sp. (26\%) and lowest was Memnoniella sp. (0.66\%). Aspergillus flavus (19.33\%), Aspergillus niger (1\%), Chaetomium sp. (3\%), Curvularia sp. (4.33\%), Fusarium sp. (18\%), Nigrospora sp.(4\%), Penicillium sp. (2\%), Rhizopus sp. $(1 \%)$ and sterile mycelium $(3 \%)$ were also found in this sample

Prevalance of Fusarium sp. (33.33\%) was recorded highest in the sample of Bilaspur and lowest was Aspergillus fumigatus (1\%) and Curvularia sp. (1\%). Alternaria sp. (17\%), Aspergillus flavus (16.33\%), Aspergillus niger (1.33\%), Nigrospora sp.(5.66\%), Rizopus sp. (3.33\%), Trichoderma sp. (1.66\%) were also found in the sample of Bilaspur.

From the sample of Ambikapur, Aspergillus flavus (22\%) was associated with highest frequency and Colletotrichum sp. (1\%) and Penicillium sp. (1\%) was associated in lowest frequency in this sample. Alternaria $s p$. (20.66\%), Aspergillus fumigatus (4.33\%), Aspergillus niger (1.66\%), Curvularia sp. (3.33\%), Fusarium sp. (20\%), Nigrospora sp. (7.66) and Trichoderma sp. (3.33\%) were also associated with this sample.

In the sample of Jashpur, 13 species of mycoflora was recorded with the highest frequency of Fusarium sp. (26\%) and lowest frequency of Aspergillus niger (1\%) and Trichoderma sp. (1\%). Similarly Alternaria sp. (15.33\%), Aspergillus flavus (12.33\%), Aspergillus fumigatus (2\%), Cheatmonium sp. (2\%), Curvularia sp. (2\%), Memnoniella sp. (3\%), Nigrospora sp. (6.33\%), Penicillium sp.(1.33\%), Rhizopus sp. (3.66\%) and Sterile mycelium $(2.33 \%)$ were also recorded with this sample.

11 Mycoflora was observed from the sample of Dhamtari, among this Aspergillus flavus $(27.33 \%)$ was highest and Colletotrichum $s p$. $(0.33 \%)$ was lowest in frequency. Alternaria sp. (19\%), Aspergillus niger (2.33\%), Chaetomium sp. (1.33\%), Curvularia sp. (6.66\%), Fusarium sp. (22.66\%), Memnoniella sp. (1\%), Nigrospora sp.(6.33\%), Penicillium sp. (0.66\%), and Rhizopus sp. (1\%) were also observed.

Among all the mycoflora, frequency was highest of Fusarium sp. (22.94) and lowest was Penicillium sp. (1.33\%). Similarly Alternaria sp. (18.49\%), Aspergillus flavus (18.38\%), Aspergillus fumigatus (2.44\%), Aspergillus niger (2.05\%), Chaetomium sp. (1.87\%), Colletotrichum sp. (1.44\%), Curvularia sp. (4.60\%), Memnoniella sp. (1.55\%), Nigrospora sp. (5.99\%), Rhizopus sp. $(1.93 \%)$, sterile mycelium $(2.55 \%$ and Trichoderma sp. (2.58\%) were observed (Table 1).

Among all the ecological zone highest seed borne mycoflora was recorded from the sample of Bilaspur $(2.49 \%)$ and lowest from the sample of Dhamtari (0.83\%). Similarly from Raipur (2.24\%), Kawardha (2\%), Ambikapur (2.16\%), and Jashpur (2.08\%) was recorded (Fig. 1-3). 
Table.1 Mycoflora recorded from 6 ecological zone of okra

\begin{tabular}{|c|c|c|c|c|c|c|c|}
\hline \multirow[t]{3}{*}{ Mycoflora recorded } & \multicolumn{7}{|c|}{ Ecological zone } \\
\hline & 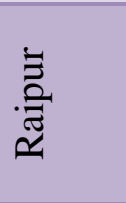 & 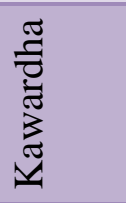 & 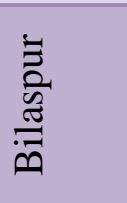 & 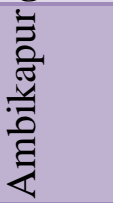 & 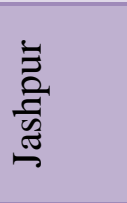 & 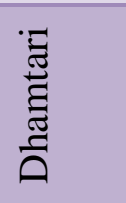 & 胥 \\
\hline & \multicolumn{7}{|c|}{ frequency $(\%)$} \\
\hline Alternaria sp. & 13 & 26 & 17 & 20.66 & 15.33 & 19 & 18.49 \\
\hline Aspergillus flavus & 13 & 19.33 & 16.33 & 22 & 12.33 & 27.33 & 18.38 \\
\hline Aspergillus fumigatus & - & - & 1.00 & 4.33 & 2.00 & - & 2.44 \\
\hline Aspergillus niger & 5.00 & 1.00 & 1.33 & 1.66 & 1.00 & 2.33 & 2.05 \\
\hline Chaetomium sp. & 1.16 & 3.00 & - & - & 2.00 & 1.33 & 1.87 \\
\hline Colletotrichum sp. & 3.00 & - & - & 1.00 & - & 0.33 & 1.44 \\
\hline Curvularia sp. & 10.33 & 4.33 & 1.00 & 3.33 & 2.00 & 6.66 & 4.60 \\
\hline Fusarium sp. & 17.66 & 18 & 33.33 & 20 & 26 & 22.66 & 22.94 \\
\hline Memnoniella sp. & - & 0.66 & - & - & 3.00 & 1.00 & 1.55 \\
\hline Nigrospora sp. & - & 4.00 & 5.66 & 7.66 & 6.33 & 6.33 & 5.99 \\
\hline Penicillium sp. & 1.66 & 2.00 & - & 1.00 & 1.33 & 0.66 & 1.33 \\
\hline Rhizopus sp. & 0.66 & 1.00 & 3.33 & - & 3.66 & 1.00 & 1.93 \\
\hline Sterile mycelium & 2.33 & 3.00 & - & - & 2.33 & - & 2.55 \\
\hline Trichoderma sp. & 4.33 & - & 1.66 & 3.33 & 1.00 & - & 2.58 \\
\hline Mean & 2.24 & 2.00 & 2.49 & 2.16 & 2.08 & 0.83 & \\
\hline
\end{tabular}

Fig.1 Mycoflora on okra seed surface

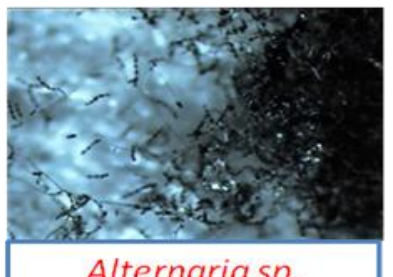

Alternariasp.
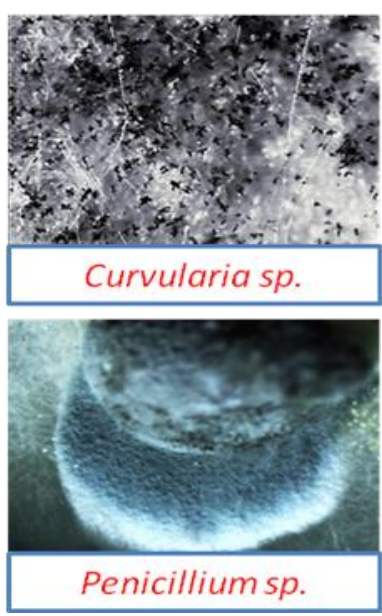
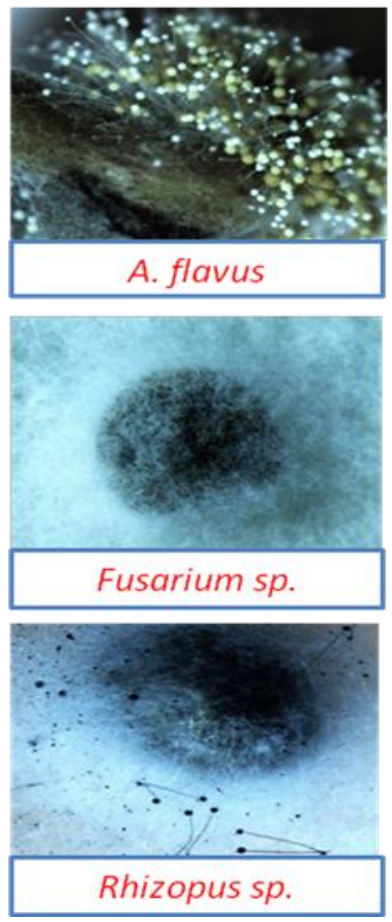
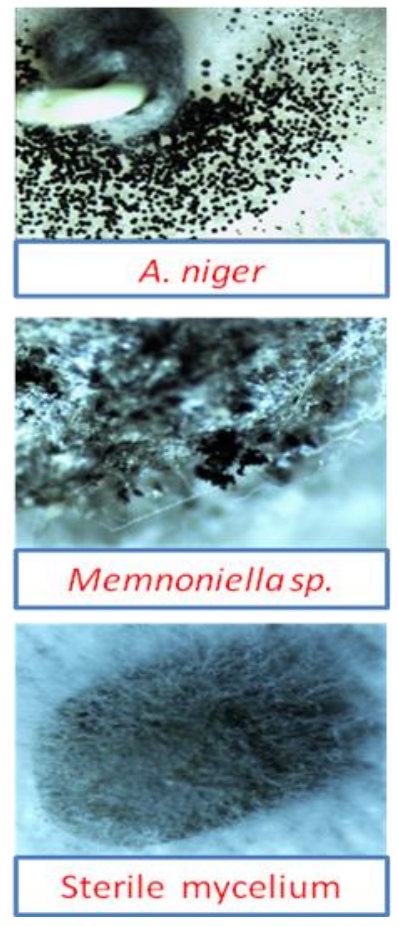
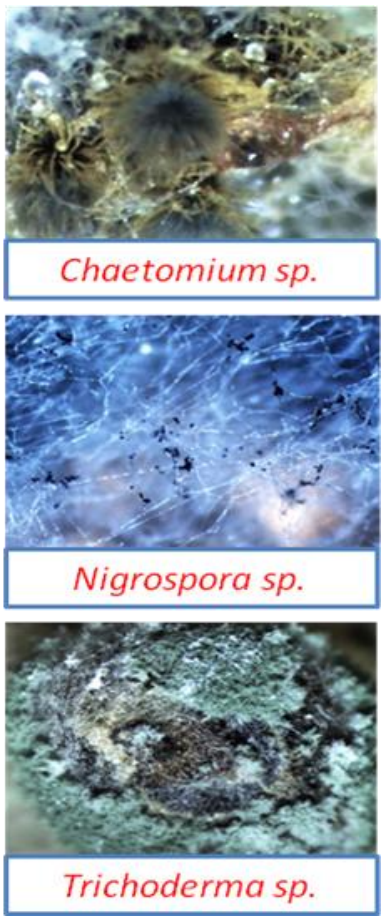
Fig.2 Microscopic view of different mycoflora observed on okra seed
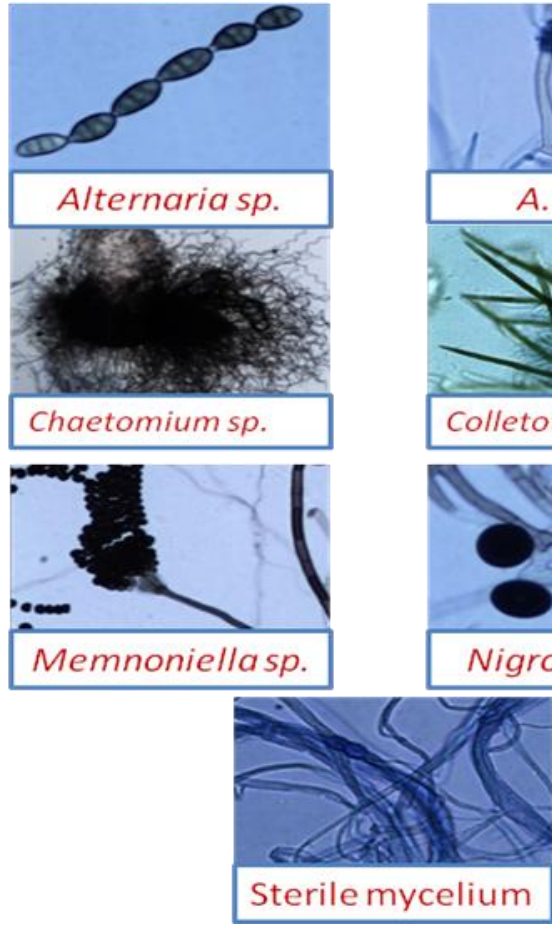
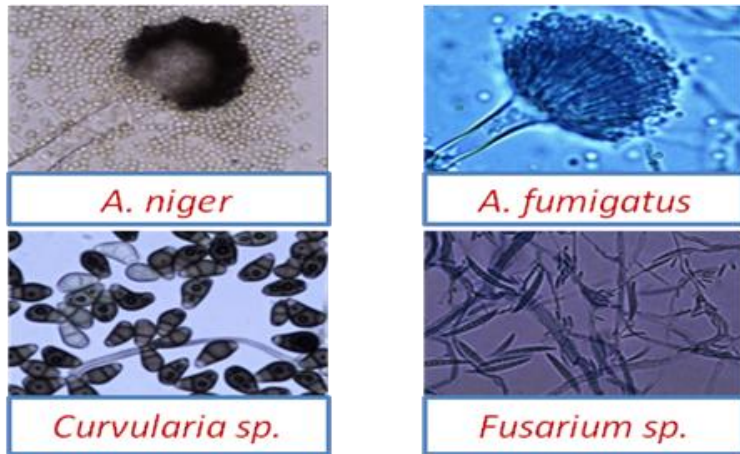

A. fumigatus

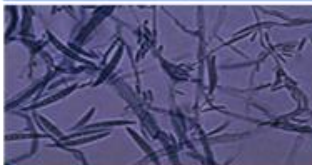

Fusarium sp.
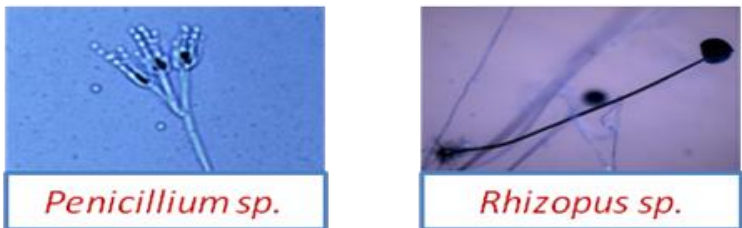

Fig.3 Culture view of mycoflora
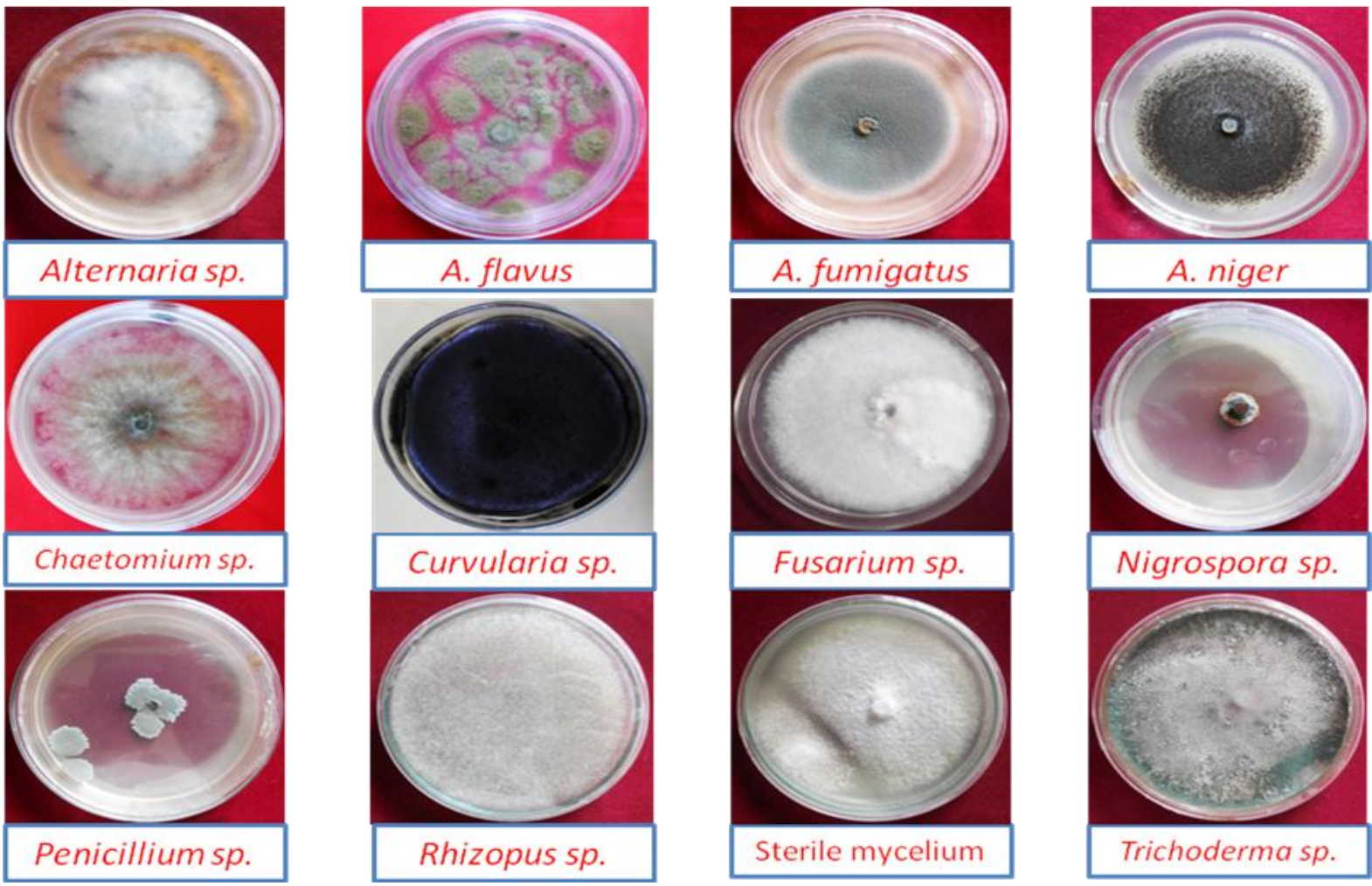
Fakir (1986) identified 17 different fungi representing 12 genera in okra as seed borne collected from three districts viz. Bogra, Mymensingh and Rajshahi. He reported the identified genera as Aspergillus, Alternaria, Colletotrichun, Corynespora, Chaetomium, Curvularia, Doratomyces, Epicoccum, Fusarium, Penicillium, Macrophomina, Rhizopus. According to him, the most prevalent fungi, in order of prevalence, were Aspergillus flavus, Chaetomium globosum, Penicillium sp., Aspergillus niger, Aspergillus sydowii, Curvularia lunata, Fusarium sp., Doratomyces sp. from seedlings. Aspergillus flavus, Botryodiplodia theobromae and Penicillium digitatum were predominant.

Fakir (1987) recorded 15 different fungi representing 10 genera in okra seeds collected from three districts Bogra, Mymensingh and Rajshahi. The genera of fungi were Alternaria sp., Aspergillus, Chaetomium, Colletotrichum sp., Curvularia sp., Epicoccum, Macrophomina, Penicillium and Rizopus sp.. The most commonly occurring fungi in order of prevalence were Aspergillus flavus, Penicillium, Fusarium spp. (F. equiseti, $F$. oxysporum, $F$. semitectum and $F$. moniliforme), Aspergillus niger, Aspergillus sydowii, Alternaria alternata, Colletotrichum dematium, Macrophomina phaseolina, Curvularia luntana and Rhizopus nigricans.

Gupta et al., (1989) investigated fungi associated with 9 samples of okra seeds collected from areas in Meerut, Uttar Pradesh, India by Blotter and Agar Plate method. They found that Alternaria alternata, Curvularia lunata (Cochiliobolus lunata) and Aspergillus flavus were the major fungi associated with discolored seeds. They also recorded Alternaria lunata, Aspergillus flavus, A. niger, Cochliobolus sp., Fusarium semitectum, F. pallidoroseum, F. monliformae and Gibberella fujikuroi from surface sterilized Sevendhari and Pusa Sawani okra seed as internally seed- borne which produced varying degrees of seed and seedling mortality.

The results of the present finding are in conformity with resultes of previous workers like Adisa and Aborisade (1987), Fernandes et al., (1992), Prasad et al., (2000) and Richardson (1990).

Among all the seed samples of okra highest mycoflora was recorded from blotter paper method and lowest was from 2,4-D method.

\section{Acknowledgement}

The authors are thankful to the Head, Division of Plant Pathology, IGKV, Raipur, C.G. for providing the facility during the course of study.

\section{References}

Adams, C. F., 1975. Nutritive value of American foods in common units, U.S. Department of Agriculture, Agric Handbook. 425., pp 29.

Adisa, V. A. and Aborisad, A. I. 1987. Seedborne mycoflora of two okra cultivars and their effects on seed quality. Fitopathologia Brasileria, 12(4): 388390.

Anonymous, 2013. Indian Agriculture. Vikas Singhal for Indian Economic Data Research Centre, Maya Puri, New Delhi, India. pp. 271-2.

Anonymous. 2012. United States Nutrient Database laboratory, National Nutrient Database for Standard Reference, Okra raw.

Arapitsas, P. 2008. Identification and Quantification of polyphenolic Compounds from okra seeds and skin. Food Chemical, 110:1041-1045.

Chauhan, D.V.S. 1972. Vegetable Production in India. 3rd ed. Ram Prasad and Sons. Agra. 
Fakir, G. A. 1987. Annual Progress Report. Seed Pathology sub-project. Dept. of Plant Pathol., BAU., p.20.

Fakir, G. A. 1977. Detection of seed-borne fungi in okra, their role and control. A monograph accepted by the Danish Government Institute of seed Pathology, Copenhagen, Denmark.p.22.

Fakir, G. A. 1986. Annual Progress Report. Seed Pathology sub-project. Dept. of Plant Pathol., BAU, Mymensingh.p.17.

Fakir, G. A. 2000. An annotated list of seed borne diseases in Bangladesh. Seed Pathology Laboratory, Department of Plant pathology, Bangladesh Agricultural University Mymensingh. pp. 20.

Fakir, G. A. and Mridha, A. U. 1985. Dieback caused by Colletotrichum dematium and Macrophomina phaseolina a new disease of lady's finger (Hisbiscus esculentus L.) Bangladesh J. of Plant Pathol.1: 2528.

Fernandes, M., C et al., 1992. Preliminary studies of health testing in okra seed from different municipalities of Rio de Janerio State. Rev. Plant Pathol., 72(10): 796.

Gupta, K., I. R. Sindhu and Nazz, S. 1989. Seed mycoflora of Abelmoschus esculentus (L.) Mocnch; A survey and enumeration. Acta-Botanica- Indica. 17(2): 200-206.
I.S.T.A. 1999. International Seed Testing Association. International Rules for Seed Testing. Rules amendments. Seed Science and Technology. 29(2): 1-127.

Moekchantuk, T. and Kumar, P. 2004. Export okra production in Thailand Intercountry Programme for vegetable IPM in South and SE Asia Phase II. Pp. 111 -128 .

Muskett, A.E., and Malone, J.P. 1941. The Ulster method for the examination of flax seed for the presence of seed borne parasites. Ann. Appl.Biol., 28 : 8-13.

National Research Council. 2006. "Okra". Lost Crops of Africa: Volume II: Vegetables. Lost Crops of Africa.

Neergaard, P. 1979. Seed Pathology, Vol. I. The Mac Millan Press Ltd., London. p. 839.

Prasad, B. K. et al., 2000. Storage fungi of lady's finger seed and their significance. J. Phytol. Res., 13 (1): 65-68.

Richardson, M. J. 1990. An annotated list of seed-borne diseases (Fourth edition). The International Seed Testing Association, Zurich, Switzerland. pp.183-184.

Valeriana, P. J. 2002. Training resource text on crop development, major economic practices, disease and insect ecology, insect pests, natural enemies and disease of okra.

\section{How to cite this article:}

Praveen Banvasi, C. P. Khare, G. K. Awadhiya, Veer Singh and Dheeraj Baghel. 2019. Study of Seed Mycoflora in Different Samples of Abelmoschus esculentus (L.) Moench. Int.J.Curr.Microbiol.App.Sci. 8(12): 2426-2433. doi: https://doi.org/10.20546/ijcmas.2019.812.285 